\title{
PEMANFAATAAN EQUATION EDITOR DALAM PENULISAN NOTASI MATEMATIKA MAHASISWA PENDIDIKAN MATEMATIKA UNIVERSITAS BALIKPAPAN
}

\author{
Ryan Angga Pratama \\ Program Studi Pendidikan Matematika FKIP Universitas Balikpapan \\ Jl. Pupuk Raya, Balikpapan, \\ ryananggapratama13@gmail.com
}

\begin{abstract}
ABSTRAK
Bidang matematika tidak terlepas dari notasi, lambang, maupun symbol; serta pentingnya dalam representasi dari semua hal itu, sehingga pemanfaatan Equation Editor dalam penulisan notasi ilmiah di tugas-tugas mahasiswa, makalah, artikel, bahkan pembuatan bahan ajar sekalipun sangatlah diperlukan. Hal ini disebabkan mahasiswa kurang terbiasa memaksimalkan fitur Equation Editor yang terdapat di MS Word. Penelitian ini bertujuan untuk mendeskripsikan pemanfaatan fitur Equation Editor dalam tugas Makalah mahasiswa FKIP Universitas Balikpapan sebagai calon guru profesional. Untuk itu, digunakanlah metode penelitian deskriptif kualitatif, dengan subyek penelitian terdiri dari yakni 19 mahasiswa dari Kelas A dan 40 mahasiswa dari kelas B, dimana pengumpulan datanya dengan observasi, wawancara, dan triangulasi. Setelah dilaksanakan penelitian, ditemukan bahwa jenis kesalahan yang dilakukan hampir sama, yakni kesalahan konsep dasar dalam pemanfaatan Equation Editor, notasi dalam operator perkalian, serta kebiasaan yang sulit dihilangkan dalam memanfaatkan fitur Equation Editor. Kesalahan konsep yang dilakukan siswa dikarenakan kurangnya pemahaman mahasiswa dalam memaksimalkan fitur-fitur yang terdapat di MS Word khususnya Equation Editor, serta kebiasaan terdahulu yang sulit dihilangkan dalam menyusun Makalah yang standar dan apa adanya tanpa memerhatikan notasi dan symbol matematika. Hal ini juga didukung oleh hasil diskusi dan wawancara dengan rekan dosen, dimana menurutnya para mahasiswa dari semester-semester sebelumnya juga tidak begitu memerhatikan pentingnya penggunaan Equation Editor dalam penulisan notasi dan symbol matematika di MS Word, hal ini sudah menjadi kebiasaan bagi mereka dan dosen pun juga tidak begitu teliti akan hal itu, hanya melihat dan menilai isi/konten Makalah bukan dari sisi pemanfaatan Equation Editor
\end{abstract}

Kata Kunci : penulisan, notasi matematika, equation editor

\begin{abstract}
In mathematics, not only talking about numbers, but also about symbols; and represented about all of them. So that, using Equation Editor is very important for writing of scientific notation in student's tasks, papers, or making a module when they are become a teacher. In fact, students of mathematics education programme in University of Balikpapan not usual using equation editor in Microsoft Word's feature. This research objective is to describe students' behavior about writing of mathematics symbols with equation editor. The research method used Description Research. This research was conducted in the University of Balikpapan. The subject of this research was the students in the $4^{\text {th }}$ semester (19 students in Class A and 40 students in Class B), in which data collected by observation, interview, and triangulation. After doing all of these method, it was found kind of mistakes about writing scientific notation from students's tasks or papers. In this case, our students not understanding about equation editor's basically concept, custom writing, and they can't upgrade their skill in Microsoft Word. This research is supported by result of discussion and interview from other
\end{abstract}


lecturers. Their opinion, the content of tasks or papers more important than using equation editor for writing mathematics's symbols. Hence, using equation editor in Microsoft Word's feature is important for students to be a professional teacher in the future.

Keywords: writing, mathematics's symbols, equation editor

\section{Pendahuluan}

Matematika merupakan ilmu universal yang mendasari perkembangan teknologi modern, berperan penting dalam berbagai disiplin ilmu, dan mengembangkan daya pikir manusia (Masykur dan Fathani, 2007; In'am, 2012). Besarnya peranan tersebut, menjadikan matematika sebagai mata pelajaran wajib di sekolah, dan perlunya penguasaan konsep yang kuat sejak dini. Bahkan dapat dikatakan jika suatu negara mengabaikan pendidikan matematika sebagai prioritas utama, maka negara tersebut akan tertinggal dari negara lain (Masykur dan Fathani, 2007).

Penyelenggarakan pembelajaran matematika yang baik dan bermutu di sekolah adalah suatu keharusan yang tidak dapat ditawar lagi (Masykur dan Fathani, 2007). Guru sebagai ujung tombak pendidikan merupakan sosok yang bertanggung jawab langsung untuk meningkatkan kualitas pendidikan melalui peningkatan kualitas pembelajaran yang dikelolanya (Azrai dan Refirman, 2013). Selain itu, perlu juga adanya pengenalan dan pemahaman penulisan notasi matematika yang baik dan benar. Untuk itu, perlu adanya pengenalan dan pembiasaan penulisan notasi matematika yang baik dan benar sejak dini, yakni didahului dari para calon guru itu sendiri, dalam hal ini mahasiswa Fakultas Keguruan dan Ilmu Pendidikan (FKIP) Matematika.

Terdapat beberapa kesalahan dalam matematika, diantaranya kesalahan membaca (reading error), memahami soal (reading comprehension difficulty), kesalahan transformasi (transform error), kesalahan dalam keterampilan proses (weakness in process skill), kesalahan dalam menggunakan notasi (encoding error), dan kecerobohan atau kurang cermat (corelles error) (Newman dalam Clement, 1980). Adapun yang menjadi focus dalam penelitian ini adalah ebrkaitan dengan kesalahan dalam menggunakan notasi (encoding error). Penggunaan simbol atau notasi matematika secara tepat juga merupakan tujuan pembelajaran matematika dalam rangka mengkomunikasikan masalah secara lebih efisien dan tepat dengan bahasa matematika. Oleh karena itu, jika terjadi kesalahan penulisan simbol yang dibiarkan, hal tersebut akan mengganggu 
siswa (mahasiswa) untuk mempelajari matematika lebih lanjut (Yunarni dkk, 2015). Dengan penggunaan simbol atau notasi matematika secara tepat, diharapkan menjadikan mahasiswa FKIP sebagai calon guru dapat memberikan pembelajaran matematika ke siswa menjadi lebih benar, baik dari sisi konsep maupun penulisan notasinya.

Lebih lanjut, Acravi (Yunarni, 2015) menguraikan beberapa fakta yang terkait dengan pemahaman terhadap simbol-simbol matematika, diantaranya yaitu: (1) mengenal simbol dengan baik, yakni pengenalan yang terdiri atas pemahaman terhadap simbol dan perasaan estetika tentang kekuatan symbol, (2) memiliki kesadaran bahwa seseorang dapat menguasai hubungan simbolik yang berupa kemahiran verbal atau informasi grafikal membutuhkan suatu proses dalam penyelesaian masalah, (3) memiliki kemampuan memilih salah satu kemungkinan representasi simbolik untuk suatu masalah, (4) realisasi kebutuhan untuk mengecek makna symbol, serta (5) realisasi bahwa simbol dapat memainkan peraturan yang berbeda dalam konteks yang berbeda.

Penulisan notasi matematika yang baik dan benar dapat dilakukan dan mulai dibiasakan oleh mahasiswa melalui pemanfaatan fitur Equation Editor di MS Word. Menurut Leas (Elshaiekh, 2013), fitur Equation Editor merupakan salah satu solusi dalam mengatasi permasalahan dalam penyisispan symbol matematika. Bidang matematika tidak terlepas dari notasi, lambang, maupun symbol; serta pentingnya dalam representasi dari semua hal itu (Sutra, 2009), sehingga pemanfaatan Equation Editor dalam penulisan notasi ilmiah di tugas-tugas mahasiswa, makalah, artikel, bahkan pembuatan bahan ajar sekalipun sangatlah diperlukan.

Meskipun mutlak diperlukan diperlukan, namun kenyataan di lapangan menunjukkan bahwa Equation Editor masih kurang dikuasai oleh sebagian besar mahasiswa. Mereka terbiasa menulis/mengetik notasi matematika dengan copy paste makalah orang lain, sekadar mengetik biasa tanpa memerhatikan insert-Equation Editor, dan semasa bangku SMA hingga perkuliahan saat ini pun tidak dibiasakan untuk menggunakan Equation Editor. Kesulitan tersebut dapat dilihat dari hasil tugas mahasiswa, yang berupa kesalahankesalahan dalam menuliskan notasi matematika. Dalam hal kesalahankesalahan penulisan tersebut, perlu ditemukan dan dipastikan sumber permasalahannya, serta menanganinya melalui suati pendekatan analisis. Dengan begitu, hasil analisis tersebut dapat dijadikan referensi penyusunan strategi 
perbaikan yang lebih baik ke depannya, sehingga baik guru maupun mahasiswa FKIP sebagai calon guru profesional dapat memahami betapa pentingnya penulisan notasi matematika sesuai dengan kaidah fitur Equation Editor. Elsheikh \& Nadji (2013) pun memaparkan betapa pentingnya pemanfaatan fitur penulisan notasi dan symbol matematika melalui teknologi computer memudahkan siapapun, meningkatkan komunikasi dan representasi matematika, serta dapat berperan dalam mengembangkan keprofesioanalan guru maupun siswa (mahasiswa).

Berdasar pemaparan inilah, penulis merasa perlu mengungkap dan mengidentifikasi bagaimana kesalahan mahasiswa dalam menuliskan notasi matematika, khususnya dalam tugastugasnya dalam Makalah maupun tugas pengetikan lainnya, sehingga kesalahan serupa dapat diminimalisir demi tercapainya tujuan pembelajaran, peningkatan kualitas, maupun bekal FKIP sebagai calon guru profesional dapat memahami betapa pentingnya penulisan notasi matematika sesuai dengan kaidah fitur Equation Editor. Untuk itu, masalah dalam penelitian ini dirumuskan sebagai : Kesalahan apa saja yang dialami mahasiswa dalam menuliskan notasi matematika, khususnya dalam tugas- tugasnya dalam Makalah maupun tugas pengetikan lainnya?.

\section{Metode Penelitian}

Metode penelitian yang digunakan adalah deskriptif kualitatif, yang bermaksud untuk mendeskripsikan dan menganalisa fenomena, peristiwa, aktivitas, sikap, persepsi, dan pemikiran orang secara individual atau kelompok (Sa'ud, 2007), serta untuk memahami fenomena apa yang dialami subyek penelitian, baik perilaku, persepsi, motivasi, tindakan, dan lain-lain secara holistik (Moleong, 2013).

Penelitian ini dilaksanakan di Kampus Universitas Balikpapan, dimana subyek merupakan mahasiswa yang menempuh mata kuliah Teori Bilangan yang dipilih secara purposive sampling, yakni 19 mahasiswa semester IV dari Kelas A dan 40 mahasiswa semester IV dari kelas B. Adapun pengumpulan datanya dilakukan dengan observasi (pengamatan terhadap hasil Makalah mahasiswa tiap minggunya sejak bulan Maret hingga Mei), dokumentasi, serta wawancara dengan beberapa mahasiswa secara tak terstruktur.

Selanjutnya, aktivitas dalam analisis data yang dilakukan adalah sebagai berikut : 1) memeriksa hasil Makalah mahasiswa (dibagi menjadi beberapa kelompok) satu per satu sesuai dengan 
langkah-langkah yang ditentukan, 2) mendeskripsikan hasil Makalah tersebut, 3) mendeskripsikan kesalahan-kesalahan yang dilakukan mahasiswa dalam penulisan notasi matematika, 4) mengelompokkan jenis-jenis kesalahan yang dilakukan mahasiswa berdasarkan kriteria yang telah ditetapkan, 5) melakukan wawancara pada beberapa mahasiswa yang dianggap dapat mewakili untuk mengetahui penyebab kesalahannya. Adapun untuk validasi data dilakukan dengan teknik triangulasi, yaitu dengan membandingkan data hasil deskripsi Makalah dan data hasil wawancara. Analisa diperoleh dari hasil deskripsi kesalahan dari Makalah mahasiswa, wawancara, dan dokumentasi.

\section{Hasil dan Pembahasan}

Berdasarkan hasil dari pengumpulan tugas Makalah, terdapat beberapa kesalahan yang dilakukan oleh mahasiswa dari tiap kelompok di tiap minggunya. Adapun di minggu pertama, penulis melakukan Kontrak Perkuliahan dan perkenalan mengenai materi selama 1 semester. Minggu kedua, dilakukan sosialisasi pemanfaatan Equation Editor dalam penulisan Makalah mahasiswa Pendidikan Matematika agar terbiasa sejak dini dalam menggunakan notasi dan symbol matematika yang baik dan benar.
Pada minggu ketiga, dikumpullah Makalah mahasiswa dengan topic "Konsep Dasar Bilangan”. Berikut deskripsinya :

5) Himpunan Bilangan Irasional
Bilangan Irasional adalah bilangan riil yang tidak bisa dibas
berhenti). Dalam hal ini, bilangan irasional tidak bisa dinyatak
sebagai bilangan bulat dan b tidak sama dengan nol.
merupakan bilangan rasional. Contoh yang paling populer
bilangan $\mathrm{n}, \sqrt{2}$, dan bilangan e.
$\begin{aligned} \text { Bilangan } n \text { sebetulnya tidak tepat, yaitu kurang lebih } 3.14 \text {, } \\ =3,1415926535 \ldots \text { atau } \\ =3,1415926535897932384626433832795028841\end{aligned}$

Gambar 1. Hasil pekerjaan mahasiswa di minggu ketiga

Pada gambar tersebut, tampak bahwa mahasiswa masih menggunakan "Symbol", bukan "Equation". Tampak sekali perbedaan dari kedua fitur tersebut dari hasil pengetikannya. Tidak salah, namun jika menggunakan equation seharusnya menjadi $\pi, \sqrt{2}$, dan $e$. Selain itu, mahasiswa juga hanya melakukan crop dari pdf, sehingga tampak sekali mahasiswa menumpuk jpg sehingga bentuknya tidak teratur sebagaimana ditunjukkan gambar berikut :

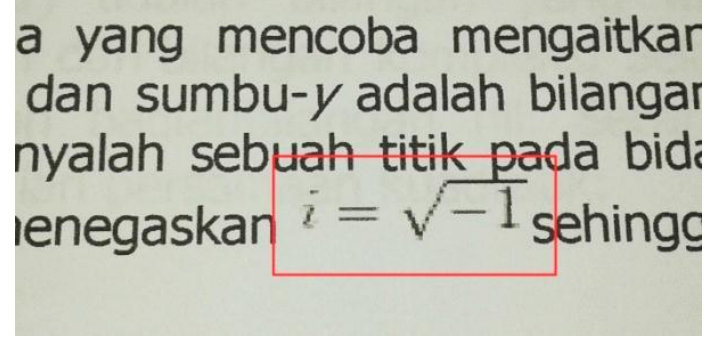

Gambar 2. Hasil pekerjaan mahasiswa yang menggunakan crop dan enggan memanfaatkan Equation Editor Pemanfaatan ... (Ryan Angga Pratama) 
Pada gambar tersebut, tampak jelas baik dari sisi font size maupun posisi kerapian penulisan menjadi tidak teratur, karena mahasiswa hanya meletakkan jpg saja. Seharusnya, mahasiswa perlu membiasakan memanfaatkan fitur Equation Editor. Selanjutnya, di minggu keempat dan kelima, kelompok mahasiswa pagi yang membahas topic "Notasi Sigma dan Induksi Matematika" sudah menunjukkan hal yang baik dalam pemanfaatan Equation Editor. Berikut gambarannya :

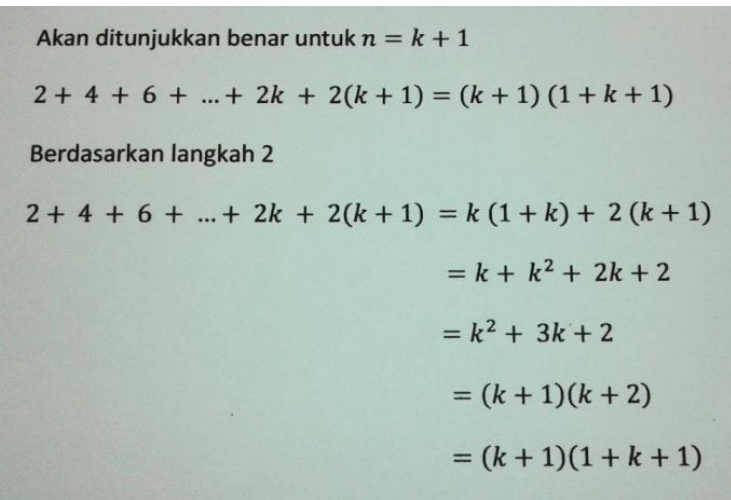

Gambar 3. Mahasiswa mulai memanfaatkan Equation Editor dengan baik

Pada hasil Makalah mahasiswa malam, masih ditemukan mahasiswa yang sekadar menggunakan crop, serta penulisan notasi matematika hanya menggunakan Symbol, seperti gambar berikut :

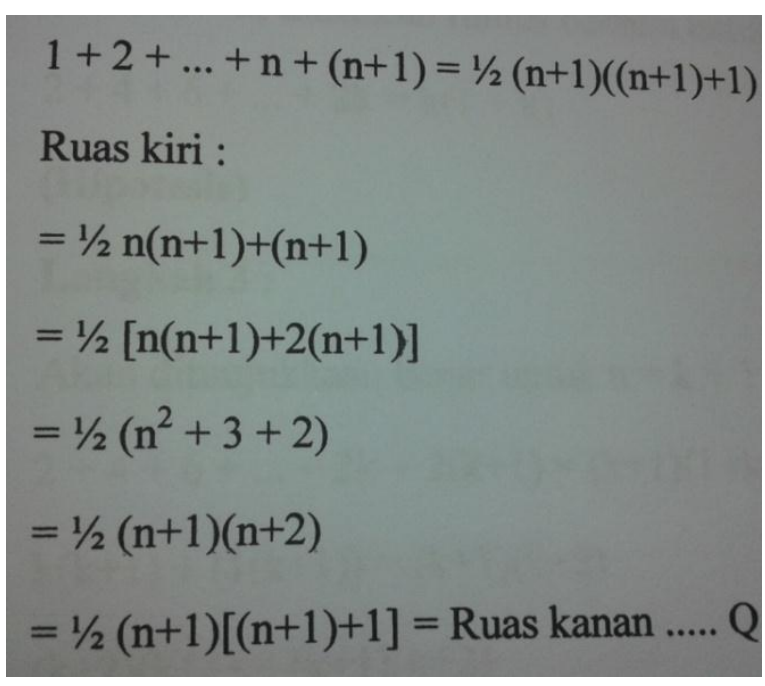

Gambar 4. Hasil Makalah mahasiswa malam di minggu keempat

Alangkah baiknya, mahasiswa mulai membiasakan diri untuk menulis dengan fitur Equation Editor, seperti “(a) $\sum_{i=1}^{n}\left(a_{i+1}-a_{i}\right)$ ”. Penomoran pasti akan sejajar rapi dengan tulisan selanjutnya, berbeda dengan jika menggunakan hasil crop. Begitu pula penulisan dengan fitur Symbol seperti " $1 / 2 \mathrm{n}(\mathrm{n}+1)((\mathrm{n}+1)+1)$ ", sedangkan jika dengan Equation Editor akan seperti ini “ $\frac{1}{2} n(n+1)((n+1)+1) ”$.

Pada minggu keenam, para mahasiswa baik dari kelas pagi maupun malam telah menunjukkan kemajuan yang sangat pesat dalam hal penulisan Makalah dengan memanfaatkan fitur Equation Editor, hal ini dapat ditunjukkan pada gambar : 


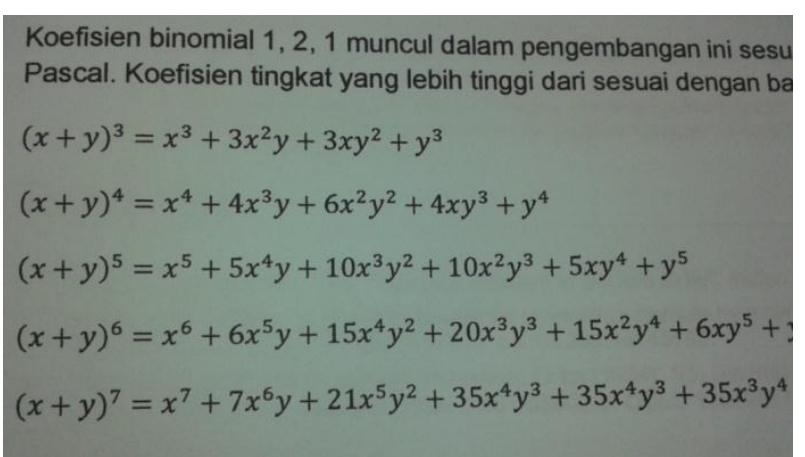

Gambar 5. Makalah mahasiswa pada topic Teorema Binomial

Pada minggu ketujuh, dilakukan review materi dan latihan soal. Adapun di minggu kedelapan dilaksanakan Ujian tengah Semester (UTS). Selanjutnya, di minggu kesembilan, penulis memberikan sebuah pengantar materi "Keterbagian", sekaligus mensosialisasikan kembali penggunaan fitur Equation Editor.

Tahap pengamatan pun dilanjutkan pada minggu kesepuluh, yakni dengan mengamati hasil Makalah mahasiswa dengan topic "Faktor Persekutuan Terbesar (FPB)". Kesalahan penulisan/pengetikan yang ditemukan seperti sebelum-sebelumnya yakni masih mengetik seperti biasa, seperti tampak pada gambar di bawah ini, terlihat penulisan variable "m" dan " $n$ " biasa saja, seharusnya dengan menggunakan Equation Editor menjadi seperti " $m$ " dan " $n$ ".
Teorema:

Misalkan $m$ dan $n$ bilangan bulat, dengan syarat $n>0$ maka $\operatorname{FPB}(\mathrm{m}, \mathrm{n})=\operatorname{FPB}(\mathrm{n}, \mathrm{r})$

Contoh:

$\mathrm{m}=60, \mathrm{n}=18$,

$60=18 \times 3+12$

maka $\operatorname{FPB}(60,18)=\operatorname{FPB}(18,12)=6$

Algoritma Euclidean

- Tujuan: algoritma untuk mencari FPB dari du

Gambar 6. Makalah mahasiswa, topik FPB

Pertemuan selanjutnya hingga minggu ketigabelas, kesalahan yang ditemukan secara umum kurang lebih seperti minggu-minggu sebelumnya. Namun, saat kelompok terakhir yang mengumpulkan Makalah dan presentasi, ditemukan kesalahan dalam penulisan operator perkalian titik (dot product). Terlihat sederhana, namun fatal bagi penulis. Hal tersebut dapat ditunjukkan pada gambar berikut :

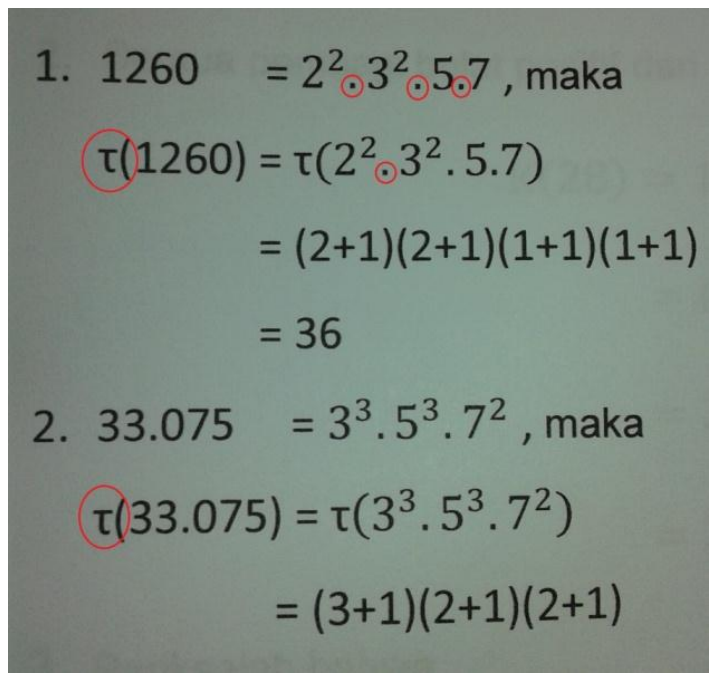

Gambar 7. Makalah mahasiswa pada topic Fungsi Tau

Notasi perkalian titik (dot product) di dalam matematika berbeda dengan 
tanda titik biasa.Terlihat pada gambar tersebut bahwa tanda titiknya berada di bawah, setara dengan tanda titik untuk mengakhiri sebuah kalimat maupun titik dalam penulisan ribuan (33.075). Jika disamakan antara perkalian titik dengan tanda titik pada penulisan ribuan, apakah 33.075 berarti 33 dikali 075? Sangat aneh, bukan? Seharusnya, mahasiswa perlu teliti dalam hal yang terlihat sedrhana ini. Penulisan yang benar melalui fitur Equation Editor seharusnya seperti " $3^{3} \cdot 5^{3} \cdot 7^{2}$ ". Tampak jelas perbedaannya, jika menggunakan Equation Editor, notasi dot product di bagian tengah notasi angka (bukan di bawah seperti di gambar). Lebih jauh lagi, di luar temuan yang ada, biasanya juga para mahasiswa terbiasa menulis soal perkalian misalnya "50 x 7" yang seharusnya "50 57 ". Tampak jelas perbedaannya, notasi perkalian disamakan dengan huruf " $x$ " (eks), padahal sangat berbeda jauh dengan notasi perkalian " $X$ ".

Pada pertemuan kelimabelas, sebelum dilakukan Kuis dan Ujian Akhir Sekolah (UAS), pada topic "Fungsi Sigma”, Makalah mahasiswa menunjukkan progress sang lebih baik seperti tampak pada gambar berikut :

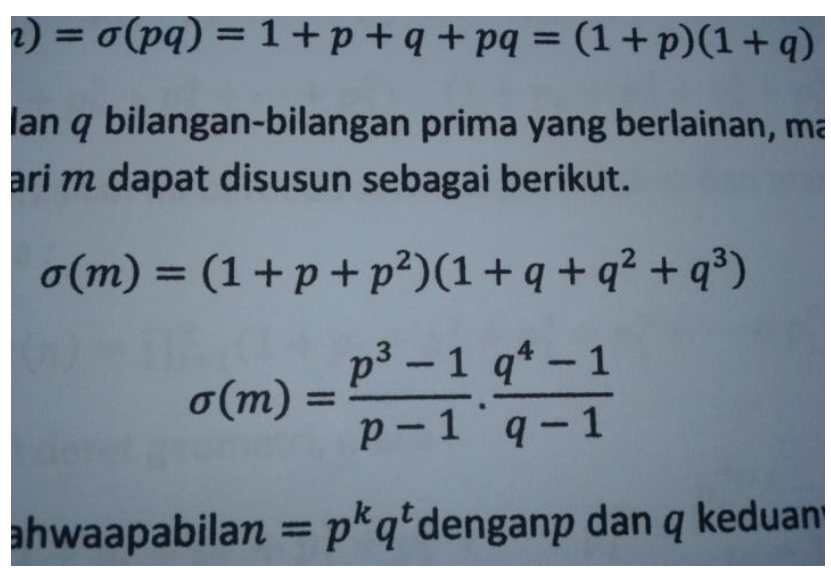

Gambar 8. Makalah mahasiswa pada topic Fungsi Sigma

Berdasarkan beberapa paparan hasil Makalah mahasiswa tersebut, secara keseluruhan kelompok mahasiswa; ditemukan jenis kesalahan yang dilakukan hampir sama, yakni kesalahan konsep dasar dalam pemanfaatan Equation Editor, notasi dalam operator perkalian, serta kebiasaan yang sulit dihilangkan untuk memulai pemanfaatan fitur Equation Editor. Kesalahan konsep yang dilakukan siswa dikarenakan kurangnya pemahaman mahasiswa dalam memaksimalkan fitur-fitur yang terdapat di MS Word khususnya Equation Editor, serta kebiasaan terdahulu yang sulit dihilangkan dalam menyusun Makalah yang standar dan apa adanya tanpa memerhatikan notasi dan symbol matematika. Adapun kemahiran mahasiswa dalam memanfaatkan Equation Editor tentunya berbeda-beda disebabkan karena factor keuletan, ketelitian, kegigihan, maupun kebiasaan 
yang dibawanya sejak semester sebelumnya.

Melihat fakta ini, perlunya peran dosen maupun mahasiswa yang bersangkutan untuk mengatasi hal tersebut, yakni dengan mulai membiasakan memaksimalkan fitur Equation Editor dalam pengetikan Makalah, Tugas, Paper, dan sebagainya yang berkaitan erat dengan notasi dan symbol matematika. Makalah mahasiswa tidak lagi hanya dilihat dari isi atau kontennya saja, melainkan diteliti dan telaah mengenai kebenaran notasi dan symbol yang digunakan. Hal ini sebagai bekal bagi mahasiswa ke depannya untuk menjadi guru professional, yang dalam tuntutannya ketika ditugaskan dalam membuat soal ulangan maupun latihan ke siswa dapat memaksimalkan fitur Equation Editor agar penulisannya menjadi baik, benar, serta terlihat indah.

Sebagaimana diketahui, hingga saat ini masih banyak guru yang mengalami kesulitan dalam memanfaatkan notasi dan symbol melalui teknologi (Elsheikh \& Nadji, 2013). Oleh karenanya, para mahasiswa FKIP sebagai calon guru generasi penerus perlu memaksimalkan dan mengembangkan dirinya dalam memanfaatkan teknologi khususnya fitur Equation Editor untuk menuliskan dan merepresentasikan notasi dan symbol matematika. Lebih lanjut, melalui representasi notasi dan symbol matematika yang baik dan benar melalui pemanfaatan teknologi dapat pula meningkatkan komunikasi bermatematika (Elsheikh \& Nadji, 2013), serta direkomendasikan kepada pakar, guru, siswa/mahasiswa, hingga peneliti di bidang matematika (Elshaiekh, 2013).

\section{Simpulan}

Berdasar hasil penelitian ini, dapat disimpulkan secara keseluruhan kelompok mahasiswa; jenis kesalahan yang dilakukan hampir sama, yakni kesalahan konsep dasar dalam pemanfaatan Equation Editor, notasi dalam operator perkalian, serta kebiasaan yang sulit dihilangkan untuk memulai pemanfaatan fitur Equation Editor. Kesalahan konsep yang dilakukan siswa dikarenakan kurangnya pemahaman mahasiswa dalam memaksimalkan fiturfitur yang terdapat di MS Word khususnya Equation Editor, serta kebiasaan terdahulu yang sulit dihilangkan dalam menyusun Makalah yang standar dan apa adanya tanpa memerhatikan notasi dan symbol matematika.

\section{Ucapan Terima Kasih}

Puji syukur peneliti haturkan kepada Allah SWT sehingga penelitian ini dapat terselesaikan. Tidak lupa juga 
peneliti sampaikan ucapan terima kasih kepada rekan-rekan mahasiswa yang terlibat, para dosen yang turut serta berdiskusi, serta rekan-rekan peneliti yang mendukung melalui untaian do'anya.

\section{Pustaka}

Azrai, E. P dan Refirman. 2013. Efektifitas Penerapan e- book sebagai Sumber Belajar Mandiri dalam Pembelajaran Biologi. Prosiding Semirata FMIPA Universitas Lampung

Clement, M.N. 1980. Analyzing Childern's Error on Mathematical Tasks. Education Studies in Mathematics, 11. 1-21

Elshaiekh, dkk.2013. Arabic Mathematical Symbol Insertion Application System Using Arabic Pack for Math Type Software. International Journal on Islamic Application in Computer Science and Technology, Vol 1 Issue 3, hal 31
Elsheikh \& Nadji. 2013. Math Keyboard Symbols and Its Effect in Improving Communication in Math Virtual Classes. International Journal of Information and Education Technology, Vol 3 No 6, hal 638 Masykur dan Fathani. 2007. Mathematical Intelligence. Yogyakarta : Ar-Ruzz Media

Moleong, L. 2013. Metodologi Penelitian Kualitatif. Bandung : PT Remaja Rosdakarya

Sa'ud, U.S. 2007. Penelitian Pendidikan Dasar. Modul pada Program Pascasarjana Pendidikan Dasar UPI. Bandung : Tidak diterbitkan

Sutra. 2009. Useful Mathematical Symbols. International Journal of Mathematical Science Education, Vol. 2, No. 1

Yunarni dkk. 2015. Profil Pemahaman Notasi Aljabar Ditinjau dari Kemampuan Verbal Sisw di Kelas V Sekolah Dasar. Jurnal Daya Matematis, Vol 3 No 1, hal 5 